\title{
The New Testament teaching on family
}

\author{
matters
}

\author{
Carolyn Osiek ${ }^{1}$ \\ Brite Divinity School, Texas Christian University (USA) \\ Research Associate: Department of New Testament Studies \\ University of Pretoria
}

\begin{abstract}
The article shows that first-century urban Christian communities, such as those founded by Paul, brought in both whole families and individual women, slaves, and others. An example of an early Christian family can be seen in the autobiographical details of the Shepherd of Hermas, whether factual or not. The article aims to demonstrate that the New Testament teaching on family gives two very different pictures: the structured harmony of the patriarchal family as presented in the household codes of Colossians 3 and Ephesians 5, over against the warnings and challenges of Jesus in the Synoptic Gospels to leave family in favor of discipleship. The developing devotion to martyrdom strengthened the appeal to denial. Another version of the essay was published in Horsley, Richard A (ed), A people's history of Christianity, Volume 1: Christian origins, 201-220. Minneapolis, MN: Fortress.
\end{abstract}

\section{INTRODUCTION}

The task of tracing a people's history of the family, or social history from below, in the first decades of the Christian movements poses some particular methodological problems. There is almost no material evidence for Christian life during the first two centuries, and literary evidence is scant, notably the New Testament and other documents of early Christian literature. Meanwhile, there is an abundance of both material and literary evidence for social and family life in the surrounding environment. The majority of it comes from the city of Rome and the nearby sites of Ostia, Pompeii, and Herculaneum,

\footnotetext{
${ }^{1}$ Prof Dr Carolyn Osiek is Professor of New Testament at Brite Divinity School, Texas Christian University, Fort Worth (TX), USA. She is a member of the International Advisory Board of HTS Theological Studies and a research associate of Dr Andries G van Aarde, Professor Emeritus, Department of New Testament Studies, Faculty of Theology, University of Pretoria.
} 
though substantial evidence has also been found at a few other sites around the Mediterranean, such as Jerusalem, Ephesus, and Carthage, and the distant site of Vindolanda on the British frontier. One of the interpretive questions is: to what extent is what happened in these locations typical of life elsewhere in the Empire at the same time?

\section{FINDING THE PEOPLE}

In a people's history of the first decades of Christianity, who are "the people"? The elite families in these societies are fairly easy to identify, and they are a small minority. In the early Empire they consist of three classes: the senatorial order, the equestrian order just below them, and the decurionate or local aristocracy in the provinces. Together they probably did not compose even as much as 5 percent of the population. Do we then exclude these power wielders and shapers of politics and assume that everyone else belongs to the people? This raises the much-debated question of how class and status operated. Class was determined by birth, and status relatively so, though it could change under certain circumstances. Wealth was expected of the upper classes, though, if impoverished, they did not lose their class membership. Status was more heavily dependent on relationships, social networks, and family reputation.

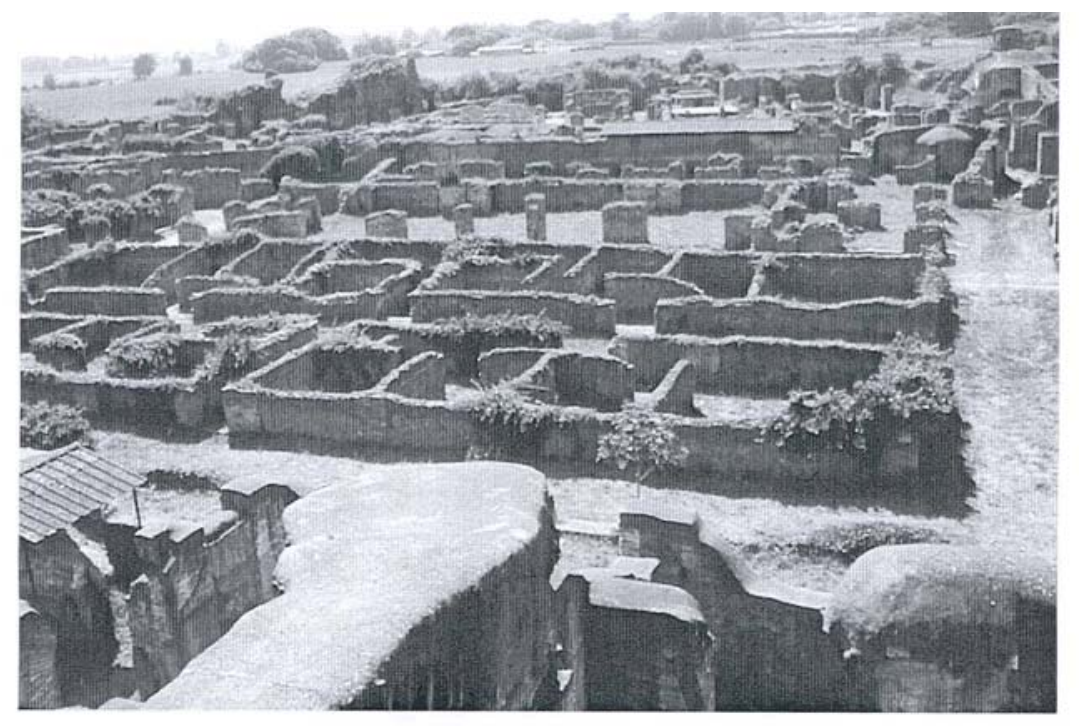

Fig 1 Foundations and first-floor walls of simple four-room apartments at Ostia, secondthird centuries CE. Each building contained four such units on the ground floor, all of similar design. A staircase indicates at least a second floor, and there were probably more.

Photo: Carolyn Osiek. 
Naming the status of early followers of Jesus is not easy. The one thing agreed upon by scholars is that there is little evidence of elites in the movement until the late second century. ${ }^{2}$ That leaves, among others, the rural poor, of whom, outside Galilee, probably few belonged to the Jesus movement, for there is not much evidence - aside from the Gospels, possibly the Didache, and Pliny's Letter to Trajan - for a rural mission movement in the early years. Even Philip's mission to Samaria has him sticking to cities and towns (Ac 8:1, 40). The church surely drew from the ranks of the freeborn urban poor and lower classes of the cities, the tradespeople, and the craftspeople. Slaves and freedpersons depended on the households with whom they were associated. Family life of some kind existed in all of these social groupings that were intricately interrelated with one another.

Early followers of Jesus lived not in their own world but the larger world of the Roman Empire. Part of the process of retrieval, therefore, is an effort to reconstruct a picture of the lives of ordinary people in cities of the Empire. Only in this way can we see early Christians in their own context and make some informed judgments about their lives based on what their contemporaries were doing and not doing. At the same time we must take into account the differences that their own writers claimed characterized the members of their movement. Apologists of the second century give the impression that Christians were just like any of their neighbors. Yet early members of the Jesus movement from Paul onwards claimed that they did not do certain things that others did commonly, such as practice divorce or abortion or abandon newborns (1 Cor 7:10-11; Didache 2.2; 5.2; Diognetus 6; Tertullian Apology 6-7, 9). But one wonders why in internal discussion they sometimes needed to place such emphasis on these differences; perhaps it was to convince not-so-convinced followers that these differences needed to be observed.

\section{GLIMPSES OF EVERYDAY LIFE}

We can learn a great deal from the remains of housing, especially what little is preserved of the lower classes and poorer inhabitants of the cities. The dark, cramped quarters of one- and two-room apartments like those of some multiple-residences buildings of Herculaneum, Pompeii, and Ostia, or the small back and upper rooms of shops in places like the main street in Ephesus are examples of the crowded, poorly ventilated, and generally unhealthy conditions in which most of the urban population lived. If such

\footnotetext{
${ }^{2}$ See further on this topic: E A Judge (1960), The social pattern of the Christian groups in the first century: Some prolegomena to the study of the New Testament ideas of social obligation; Richard L Rohrbaugh (1983), "Methodological considerations in the debate over the social class status of Early Christians"; Bruce J Malina (2000), "Social ranking, morality, and daily life".
} 
people cooked for themselves at all, it would have to have been on some makeshift portable apparatus in a nearby outside space. More likely, they bought fresh bread, fruit, and vegetables at local markets and got most of their cooked food from neighborhood vendors and thermopolia - the equivalent of fast food restaurants. They ate meat rarely if at all, typically only when present at feasts given by wealthy city patrons. If they bathed, it was in the public baths, apparently open to both men and women. They used public latrines.

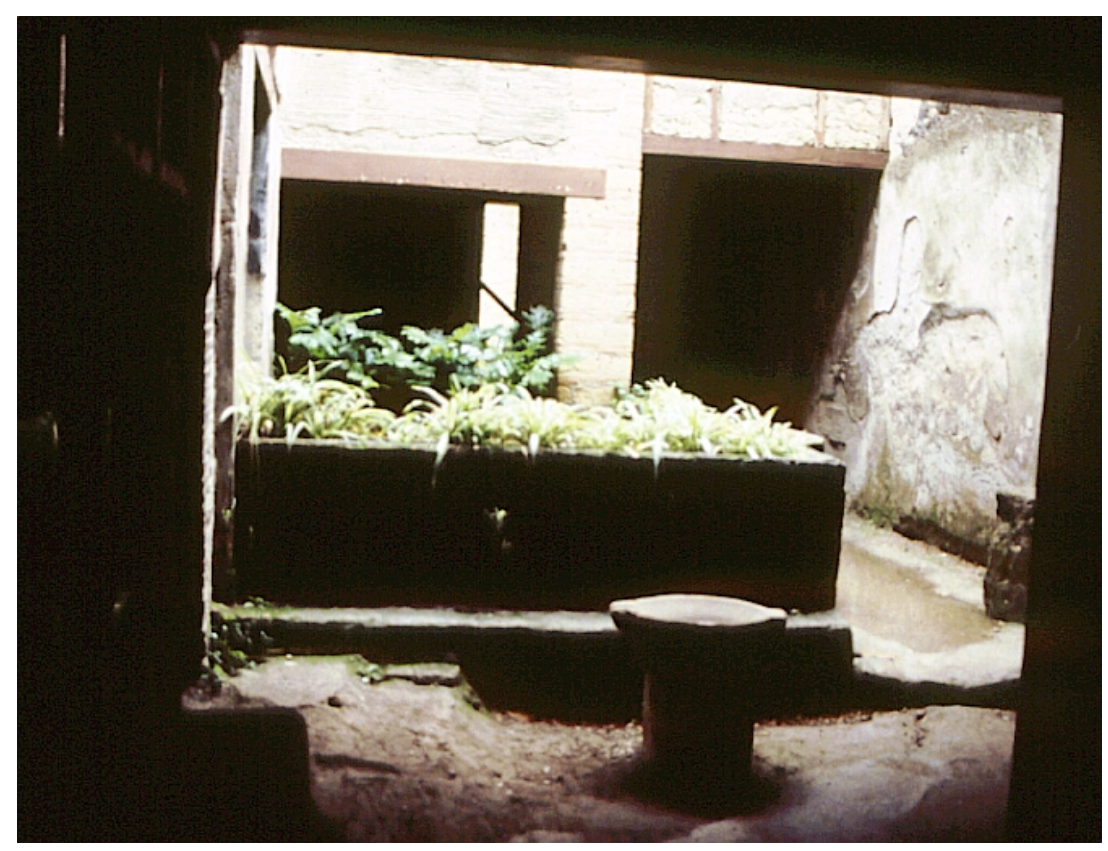

Fig 2 Courtyard and only common space of a crowded multi-resident, multi-storied apartment building, known as the Casa a Graticcio in Herculaneum, first century CE so called because of its use of a common low-standard method of construction using cemented rubble in wood frames. Such apartment houses were notorious for danger of fire and collapse.

Photo: Carolyn Osiek.

They birthed their children at home with the possible help of a midwife. They were raised in an environment of intimate social relationships and no privacy.

Material remains, of course, cannot tell the whole story. When they are combined with select literary evidence, a picture of everyday life emerges. We know little about the family life of the lower classes in the Roman Empire: it is not at all certain how much legislation affected them, and the letters that yield valuable information about how life was really lived come largely from the elites. 


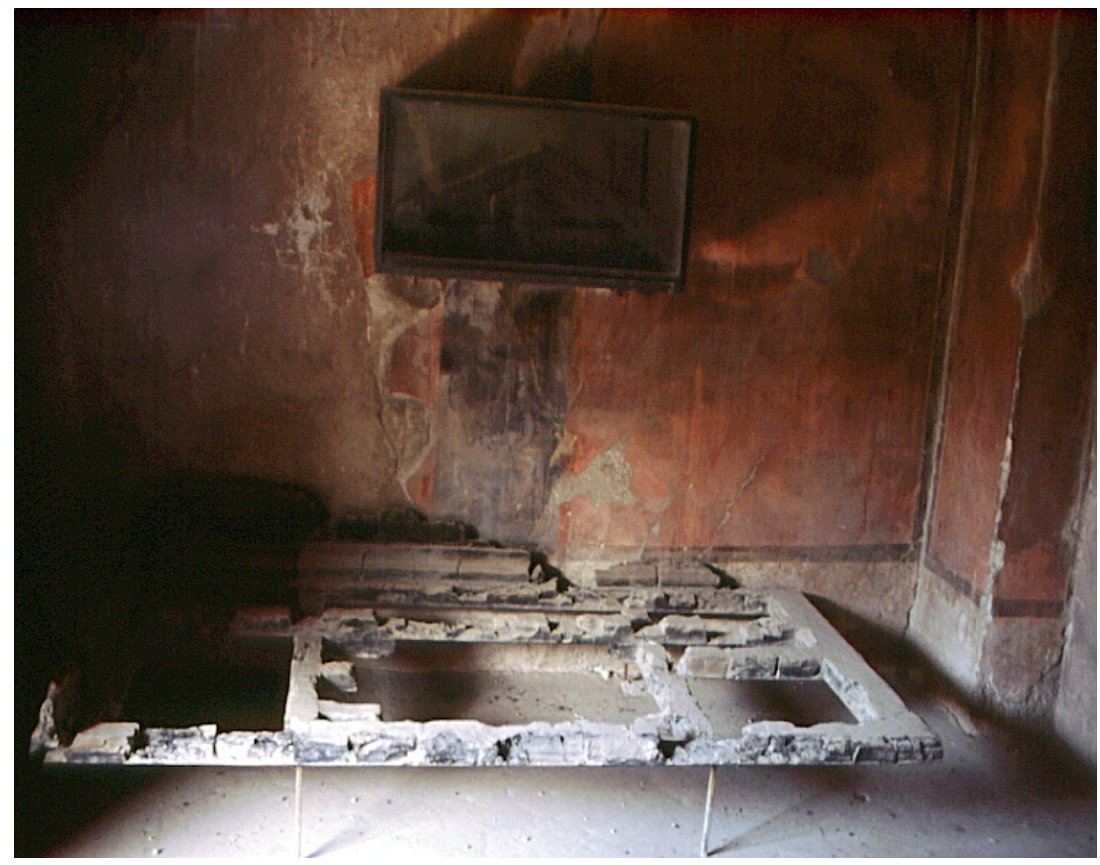

Fig 3 Single-room apartment with remains of wooden bedstead on the second floor of the same apartment building (Fig 2 above) in Herculaneum, first century CE. Remnants of a painting adorn the back wall. A whole family may have lived in such a room, cooking on a brazier outside.

Photo: Carolyn Osiek

Even inscriptions, which in the Roman era often give extensive social information, come mostly from those with sufficient wealth to be able to afford them. Sometimes, however, the most imposing monuments are not those of the elite but of people of humbler origins who have acquired enough property to be able to proclaim to the world their success and prosperity. One thinks, for instance, of the garishly imposing monument of the baker Marcus Virgilius Eurysaces and his wife, Atistia, at Porta Maggiore in Rome or the double commemoration of the freedwoman Naevoleia Tyche, who erected an imposing monument for herself and her freedman husband, Gaius Munatius Faustus, and their familia of freedmen and freedwomen outside the Herculaneum Gate at Pompeii, but whose remains were found, with those of her husband, in a simple tomb in a different cemetery area. ${ }^{3}$

The poor inhumation and incineration burials of the open field at Isola Sacra near Ostia probably once had such family information painted on their clay tiles, now disappeared. And beyond these, there was the feared common public burial ground. To avoid that unacceptable alternative, burial societies of tenuiores, or little people, were common. Members would meet regularly, usually once a month, and make a modest contribution into a common chest.

\footnotetext{
${ }^{3}$ Discussion with photo in John R Clarke 2003), Art in the lives of ordinary Romans: Visual representations and the non-elite viewers in Italy, 100 BC-AD, pp 184-185.
} 
These gatherings functioned as social clubs as well, but their express and ultimate purpose was to provide a decent burial for their members, who otherwise feared not to be able to afford it. The late second-century theologian/apologist Tertullian describes the monthly contribution of Christians toward burials and other charitable works in very similar terms (Apology 39.6). Guilds and social clubs of those who had a common trade were also readily formed. Patronage of these burial societies and workers' associations was part of the honorable behavior of the elite, both men and women. It earned them statues, inscriptions, and glory from the grateful members.

Whether for upper or lower classes, standards of sanitation and safety left much to be desired. Disease was rampant and life expectancy low. With no knowledge of how diseases spread, inhabitants were defenceless against it, especially in the large cities. Most methods of prevention and healing were folk remedies or magical incantations with very mixed success. Garments made of wool, the standard material for most clothing, were bleached with urine, both human and animal, before being treated with other chemicals, including sulphur, and washed. Most hygiene arrangements were primitive. Apartment buildings and larger houses had their own common latrines, but no centralized plumbing for waste removal. Public latrines were accessible to all, seemingly for both sexes. Defecation and urination were not considered private functions.

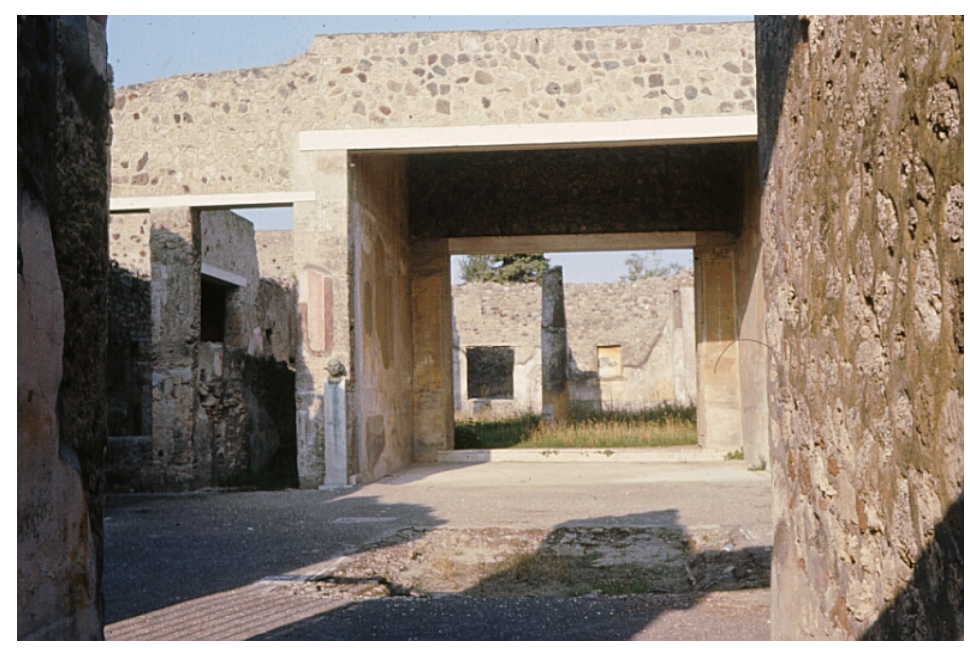

Fig 4 House of Lucius Caecilius Jucundus, son of a freedman, at Pompeii, first century CE. This simple domus illustrates the relative wealth possible for a freedman and his immediate descendants. The owner was involved in a number of business ventures, as witnessed by the records he left behind.

Photo: Carolyn Osiek 
The cities had public baths, accessible to everyone, and these promoted cleanliness and hygiene but could also be a way of spreading disease. Diseases like malaria and tuberculosis were indigenous in many areas; no one had knowledge of how they were spread. The use of lead piping to bring in the city water supply was common, with no one aware of the health hazards involved in the use of lead. Lacking knowledge of bacteria or how to kill them, people had no way except visual and olfactory inspection to know whether water was drinkable or not. Though there were famous medical schools in existence by this time and scholarly medical manuals being written, actual knowledge of diseases and how to prevent and treat them was very primitive. Generally, if the body could not heal itself of disease and illness, the person simply died. Illnesses like influenza, pneumonia, or appendicitis were surely fatal. ${ }^{4}$

Child mortality was extremely high. If one survived the first year or so, life expectancy rose considerably, but never beyond about forty years. By the time a child reached the age of ten, half of his or her birth cohort were dead. Few children grew to adulthood with both parents surviving. The customary age disparity at first marriage, in which the husband was as many as ten to fifteen years older than the bride, resulted years later in many marriageable widows. In times of war, the imbalance may have evened out as male mortality mounted. But even in times of peace, the high incidence of women's death in childbirth also contributed to balancing out the population. Probably more among the elites than ordinary people, girls were often married by the age of twelve and sometime pregnant even before their first menstruation. Early and constant childbearing took a terrible toll on their health.

The health of most inhabitants must have been rather miserable most of the time. With the possible exception of the pampered wealthy, people were old, with rotting teeth and poor eyesight, by about the age of thirty. Diseases associated with malnutrition must have been abundant, especially among the poorer segments of the population. A few survived into their seventies, eighties, and perhaps even nineties. Those who were still alive at these advanced ages, however, represented one percent or less of their birth cohort. Skill in counting years of age varied. Roman epitaphs sometimes record age at death not only by years, but by months and days. Yet in other cases, age is estimated or guessed at, sometimes with the approximation symbol \pm , "plus minus," "more or less."

Another factor to take into account when trying to get some sense of the world in which the first followers of Jesus lived is the level of violence and

\footnotetext{
${ }^{4}$ See Alex Scobie (1986), "Slums, sanitation, and mortality in the Roman world", for further details on health and hygiene.
} 
overt sexuality to which they were constantly exposed. First of all, artistic representations in everything from official civic art to the paintings on the walls of private houses graphically portrayed violent scenes: battles between armies, fights between two individuals, gladiatorial shows, mythological battles and conflicts, mythological stories depicting torture, and animals fighting and devouring one another, the last usually a lion attacking a bull, deer, or other defenseless animal. These artistic representations must have created a level of desensitization that enabled the inhabitants to view the real thing. Public executions were carried out in the most brutal way possible, and public games featured varying forms of violent entertainment: animal against animal, animal against gladiator, gladiator against gladiator, and execution of criminals by animal attack and whatever other ingenious ways could be thought up, often the enactment of the same mythological stories of torture and death depicted in sculpture and painting. ${ }^{5}$ In a culture in which the thirst for blood is mostly satisfied vicariously in competitive sports and artificial representation in film and television, it is very difficult to imagine what life was like when surrounded constantly by such a level of actual violence in public adornment and entertainment.

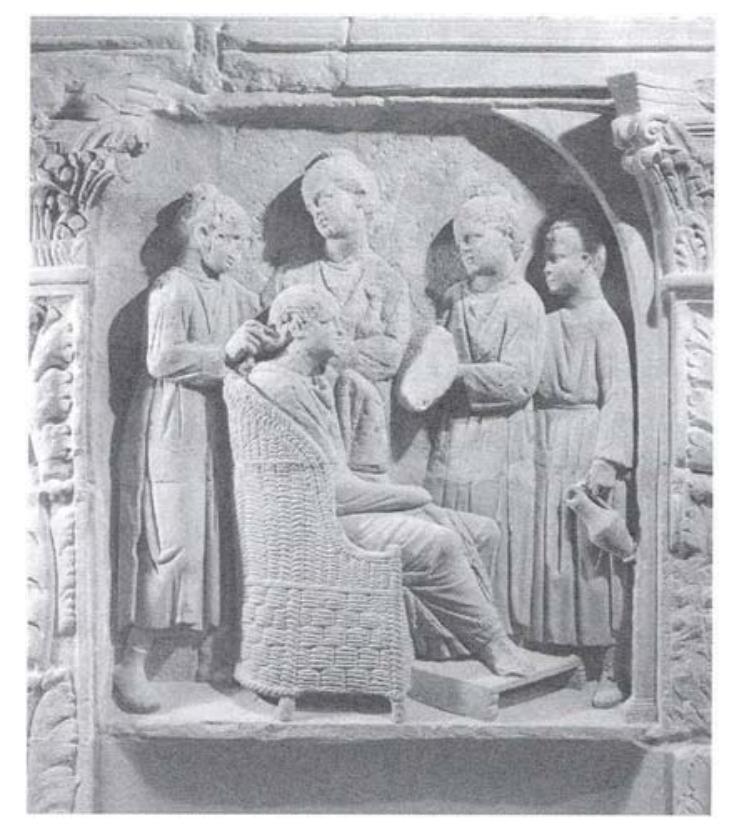

Fig 5 Four servants assist in a lady's toilet. Roman relief, second or third century CE. Rheinisches Landesmuseum, Trier, Germany.

Photo: Erich Lessing / Art Resource, NY.

${ }^{5}$ Cf Donald G Kyle (1998), Spectacles of death in ancient Rome; (1998), "Fatal charades:
Roman executions staged as mythological enactments". 
Nor was violence limited to civic uses. Slavery was an institution maintained by the threat and use of violence. Slaves were punished by beatings, torture, and executions. Every slave knew the consequences of breaking the rules or of just being in the wrong place at the wrong time. For example, four hundred household slaves of Lucius Pedanius Secundus were executed under Nero, according to ancient custom, in spite of pleas for mercy both in the Senate and from the public. This was because their master had been murdered in his urban house; the assumption was that someone in the household was guilty and that if someone wanted to, he or she could have prevented it (Tacitus, Annals 14.42-45). This underlying violence maintained the social system. Those who benefited from it taught their children to perpetuate it.

The schoolmasters and tutors, afforded only by the wealthy elite, assumed that children were recalcitrant and must be forced to learn by threat of punishment, which the teacher did not hesitate to carry out when necessary. Boys were raised with strict rules and expectationsto form them into strong and courageous men who could be self-disciplined and resist pain. ${ }^{6}$ In Roman discussions of child rearing, severe corporal punishment of sons was considered bad form and discouraged, though some beating of male children was condoned. Yet a clear distinction was made between the loving discipline of a father for his son and the harsh discipline with which slaves were treated. Only under Christian influence did the difference recede somewhat. Along the lines of the Stoic argument that virtue is freedom and vice is the real slavery, later Christian authors like Lactantius and Augustine lessened the rhetorical difference between slaves and sons, the result of which was the principle that, since both sons and slaves are sinners saved by Christ, so both should be equally punished for their own good! ${ }^{7}$

Sexuality, too, was inescapable from an early age. Nudity in public art and sculpture was quite common, as it was in the garden sculpture and paintings that adorned the walls of houses and other places where children might see them. ${ }^{8}$ The close quarters in which most poorer people lived made any kind of privacy impossible. Even in most well-to-do houses, young slaves attended their master or mistress for the most intimate of functions and activities. We would suspect that no one grew up innocent of sex, except the

\footnotetext{
${ }^{6}$ The same idea is present in Jewish thinking about child raising; see John Pilch (1993),

"Beat his ribs while he is young' (Sir 30:12): A window on the Mediterranean world".

${ }^{7}$ For example, Augustine, City of God 19.16. For the background of the discussion, see Richard P Saller (1994), Patriarchy, property and death in the Roman family, pp 144-50; Peter Garnsey (1999), "Sons, slaves - and Christians".

${ }^{8}$ Discussion and illustrations in John R Clarke (1998), Looking at lovemaking: Constructions of sexuality in Roman Art 100 BC-AD 250, especially chapters 6 and 7, pp 145-240. The dust jacket cover and plate 1 show part of the silver Warren cup, which portrays a young boy peeking around a door to watch two men having sex.
} 
daughters of wealthy families who were brought up in sufficiently spacious houses and deliberately shielded from public display to make them acceptable elite brides. But even in this case, there was still the household art.

An ancient Mediterranean history from below is not confined to the lives of independent poorer people. The advanced agrarian society of the firstcentury Roman Empire had no middle class as it is known today in capitalist societies, an independently wealthy middle sector of the society that is dominant in numbers. The majority were rather the peasants working the land and villages, along with the urban poor. There were certainly varying levels of poverty and wealth, however. In this noncapitalist, advanced agrarian society, prestige was not judged primarily by wealth but by status. Those who belonged to the underside of society did not have and would never have the status they envied in the small number of elites who possessed their high status from birth. They could observe these elites during public functions, and they must have been quite aware of how the entire social system was controlled by them and oriented to their opulent lifestyle. Others aimed to emulate them in whatever ways they could. There is evidence that some fortunate few who began in slavery could achieve a relatively comfortable and affluent way of life, though without the social recognition and access to public honors that they envied. Petronius's Trimalchio in his Satyricon set in firstcentury Rome, like Molière's Bourgeois Gentilhomme in seventeenth-century France, is the parody of someone, in this case a very wealthy freedman, who aspires to live as the elites live. As a result, he is brilliantly satirized and made to appear as a fool. While wildly exaggerated for the sake of satire, the figure of Trimalchio represents the elite's resentment for such people.

\section{FAMILIES IN SOCIAL NETWORKS}

Many of what we would classify as lower-class people did not live independently of their social betters. Family systems included people of many social levels, so that the houses of the wealthy were also the residences and workplaces of slaves, freedmen and freedwomen, and others who were attached to wealthy houses for a variety of reasons. It is important to realize that the different social strata in first-century Mediterranean societies were not as segregated as they are in a modern industrial city.

Older ways of classifying members of Roman society were by the first century giving way to a new division between elites, or honestiores, and nonelites, or tenuiores. This twofold categorization was fully in place by the second century and was primarily a legal distinction that applied to legal penalties: honestiores would be exiled or decapitated, while tenuiores were subject to more degrading forms of execution, including crucifixion and execution in the amphitheatre. Nevertheless, this status-conscious society created distinctions of honor and status wherever it could. 


\subsection{Social status and slavery}

Slavery remained an inhumane but widespread system in which slaves were totally vulnerable to the whims of owners. It is not possible to think of slaves together as a social class or even status. Their position derived solely from that of their owners. Imperial slaves and freedmen may have performed menial jobs but still carried imperial status. On the contrary, many imperial slaves and freedmen had responsible and sometimes powerful positions in which they had authority over high-status persons, with all the resentment that entailed. Paul's reference in Phlp 4:22 to believers in the household of Caesar is to persons of that group. Dale Martin (1990) has shown that being a slave was not necessarily degrading if one were the slave-agent of a high-status person, and even for a freeborn person to call oneself a slave of an important character, as Paul does, was not an act of humility but a claim to prestige. ${ }^{9} \mathrm{By}$ the time Christian thinking became the norm, the believer's status as slave of God and Christ were corollary claims to status.

Slaves belonged to the family, yet did not. Slaves and freed persons were usually buried with the natal family as dependents. They were present in Greco-Roman households for the morning ritual devotion to the household gods, and represented in household religious celebrations. ${ }^{10}$ Yet their status in the household, their welfare, and their very existence depended on the goodwill of their owners. They could be bought, sold, punished, and, within some legal restraints, executed at will. We cannot forget the basic brutality of the system, in which human persons were deprived of a past and a future, unable to claim natal family or legitimate offspring, and answerable with their bodies in a brutally exploitative system that early Christians did little to alleviate. $^{11}$

We will never know the numbers of slaves who were members of communities of Jesus-followers, but texts like 1 Cor 7:21-24; GI 3:28; Paul's Letter to Philemon; Eph 6:5-9; Col 3:22-4:1; 1 Tm 6:1-2 and 1 Pt 2:18-25 indicate that their numbers were not few and that Christian communities continued to have slave members who were not freed by virtue of baptism. Slaves were members of the household who sometimes converted with the owning family, sometimes on their own, and sometimes not at all. Household slaves were sometimes trusted and sometimes seen as the strangers in the

\footnotetext{
${ }^{9}$ Dale Martin (1990), Slavery as salvation: The metaphor of salvation in Pauline Christianity.

${ }^{10}$ See Carolyn Osiek and David L Balch (1997), Families in the New Testament world: Households and house churches, pp 81-87.

${ }^{11}$ Orlando Patterson (1982), Slavery as social death: A comparative study; Jennifer A Glancy (2002), Slavery in early Christianity. For a wide perspective on ancient slavery, see Allen D Callahan, Richard A Horsley, and Abraham Smith (eds) 1998, Slavery in text and interpretation.
} 
house whose betrayal was not unreasonably feared, especially since slaves could only be interrogated by the authorities under torture and thus, understandably, were highly likely to give incriminating testimony, whether true or not. ${ }^{12}$ In Martyrdom of Polycarp 6.1, it is a young male slave who, under torture, gives away Polycarp's hiding place.

Yet the stories that have come down to us also contain amazing accounts of slaves not only loyal to their owners but examples of strength and courage to all their companions. Blandina, a slave arrested with a group of Christians in Lugdunum in Gaul in 177, has a mistress also under arrest, who fears lest Blandina through weakness will not hold up under torture but recant. Instead, to everyone's amazement, Blandina turns out to be the most courageous and most enduring of all, the one who rallies the whole group, gives them courage, and is configured by the author of the account to Christ himself as she is hung on a stake (Eusebius, Ecclesiastical History 5.1.17-19, 40-42). A few years later in Carthage, North Africa, in 203, the slave Felicitas, also arrested with a group of catechumens, but with no mention of her owner (pace the frequent misconception that the highborn Perpetua is her mistress), is also a center of strength in the group, as she delivers her child in prison and prepares to die in the amphitheatre with the others.

Slave marriages and slave families existed de facto but with no legal acknowledgment, and they could be broken up at any time. The papyrus deeds of sale preserved from Egypt indicate that many slaves were minor children when sold. Many slave owners encouraged marital unions between slaves for the stability of the household and the increase of slaves. Perhaps Christian slave owners would have been less likely to separate slave families, ${ }^{13}$ yet there is no evidence of this. Though their marriages were not legally recognized, there appears to have been some social recognition, for the burial evidence that remains of them often uses the terminology of legal marriages, terminology denied to them under the law. ${ }^{14}$ Mixed marriages between slaves and freed, between slaves and freeborn, and between individuals of different clearly defined social levels existed everywhere - and were headaches for Roman legislators. We mostly know of the possibility and frequency of such marriages through their discussions. While the marriage of a free male with his female slave freed matrimonii causa (freed in order to marry him) was not unusual, marriage of a freeborn or even higher status woman with a slave or former slave was harshly condemned - but still

\footnotetext{
${ }^{12}$ J Albert Harrill (2003), "The domestic enemy: A moral polarity of household slaves in early Christian apologies and martyrdoms".

${ }^{13}$ Suggested to me by Margaret MacDonald in conversation.

${ }^{14}$ Dale B Martin (2003), "Slave families and slaves in families".
} 
practiced widely. Various penalties were intermittently applied, including reduction of the free woman to slavery by her husband's owner, a penalty enacted by the Senatus Consultum Claudianum under Claudius. Marriage of a free woman to her own slave was considered a particularly heinous role reversal between superior and inferior, incurring various social and legal penalties and culminating in the extreme of threatened capital punishment for such a woman in the fourth-century Christian legislation of Constantine. ${ }^{15}$

By the fourth century, Christians were still keeping slaves, as is attested from many sources. A testimony of somewhat equal treatment by this time is that they were sometimes singled out for religious leadership. Already in the early second century, Pliny the Younger, governor of Bithynia and Pontus, had reported in his famous account of Christian activity there that he had tortured two ancillae (female slaves) who bore the title of ministrae in their Christian community. ${ }^{16}$ Scholars continue to debate whether this Latin title is the equivalent of "deacon", given to women both earlier (Phoebe in Rm 16:1) and later. Whether it is an equivalent, it must certainly be some kind of official leadership position.

The Apostolic Canons (Apostolic Constitutions 8.47.82) of the late fourth century specify that a slave is not to be ordained to the clergy without his master's or mistress's consent, because this would upset the household. But if the owner allows it, the slave must be manumitted and dismissed from the house and can then be ordained. Similarly, Gregory Nazianzen tells a lady to whom he is writing that she must manumit a slave who has been consecrated bishop against his will (Epistle 79)! Still in the middle of the sixth century, Justinian's legislation decrees that anyone chosen to be bishop must be manumitted from slavery (Novellae 123.4). All of this is confirmation of two things: slaves could become clergy, but there is still no question of Christians abandoning the institution of slavery.

\subsection{Marriage}

Marriage between followers of Jesus and others is already reflected in 1 Cor 7:12-16 and $1 \mathrm{Pt}$ 3:1. Nothing is said there about disparity of status, but this problem is voiced later in Tertullian, To his wife 2.8.4, and Hippolytus, Refutations 9.12.24-25, because of both defiance of law and social disapproval. Tertullian notes that poverty and lowliness are not so bad for a wife to consider in her husband, in view of Christ's love of poverty. Hippolytus maintains "family values" by excoriating his rival Callistus for allowing upper-

\footnotetext{
${ }^{15}$ Evans-Grubbs, Judith (1993), "Marriage more shameful than adultery": Slave-mistress relationships, "mixed marriages," and late Roman law".

${ }^{16}$ Pliny, Epistle 10.96.8.
} 
class women to marry beneath themselves in order to find Christian husbands. Both situations reflect what we know from other sources. Christian communities, like Judean synagogues and some of the other unofficial cults, were very appealing to women, who often joined such groups independently of their husbands and families. Moreover, the Christian inversion of the social values of honor and status also led at least some Christian theorists to encourage such flaunting of custom, presumably for the sake of women's finding good marriage partners among believers.

Fully legal marriages in Roman law (conubium, matrimonium iustum) existed only between Roman citizens or Junian Latins (a category of former slaves freed informally or under the age of thirty, except a female for marriage). All other unions were concubinage (contubernium, concubinatus). It is important, however, to realize that the unfavorable connotations attached to terms like "concubinage" today did not apply. Concubinage was simply a marital union not fully recognized under the restrictive marriage legislation of Rome. ${ }^{17}$ While perhaps a good number of believers in Jesus in colony cities like Philippi or Corinth may have been Roman citizens, probably the majority overall were not. ${ }^{18}$ While the marriages of those who were not Roman citizens (certainly the vast majority in the early Empire) were recognized by local law and by community custom, they were not recognized in Roman law. By the early third century, Roman citizenship seems to have increased exponentially, so that by the time of Caracalla's declaration of universal citizenship in 212 , the legal situation with regard to marriages would have changed.

\subsection{Women}

All cultures and subcultures of the ancient Mediterranean world were publicly androcentric and patriarchal. At every level of society, men were publicly more powerful and considered superior to women. Yet this male dominance must be qualified in a number of ways. While women could not serve in elective office, there is intriguing evidence, especially from Asia Minor, of elite women holding certain civic offices. In the Roman world, status was always more important than gender; that is, higher social status always took preeminence over the sex of the persons involved. Thus in the highly developed system of patronage and benefaction, women were actively engaged at every level. They not only held property but ran businesses and exercised personal,

\footnotetext{
${ }^{17}$ Beryl Rawson (1974), "Roman concubinage and other de facto marriages".

${ }^{18}$ A general consensus has been that, because Philippi was a Roman military colony, thus with a large number of Roman citizen inhabitants, most members of the Christian community there would have been Roman citizens. This consensus has recently been challenged by Peter S Oakes (2001), Philippians: From people to Letter, who argues that only the elites of the city were Roman citizens, and both the letter and the general pattern of first-generation members give no evidence of elite membership.
} 
financial, and political patronage. Though excluded from elective office, they were able to influence politics in many direct and indirect ways. ${ }^{19}$

Under the influence of interpretations of Mediterranean anthropological studies brought into biblical scholarship, students of early Christianity are now accustomed to thinking of ancient Mediterranean societies as honor-shame cultures, in which women embody family honor, sensitivity to honor, and the possibility of shame in their conduct. In this view, women are potentially dangerous to their families as those who can easily bring shame by sexual conduct inappropriate to their state of life.

One can see this, for example, in the way the second-century BCE scribe Ben Sira frets over the troubles that a daughter brings (Sir 42:9-14). He loses sleep over worrying whether he will be able to get her a good marriage, whether she will be seduced beforehand, whether she will please her husband, and whether she will bear children. Her father is to keep careful guard over her while she is in his house to be sure there is no secret way into her room. She should not spend time with married women. He concludes that it is a woman who brings shame into the house.

This pessimistic meditation reflects a pattern that in its larger lines is generally accurate, yet it must be nuanced by consideration of other factors that contribute to the social dynamic: the way in which the kinship and hierarchy structures work in any given situation. Crucial here is the degree of women's economic control of resources, for where women have greater economic power, they also have greater social power. Another mitigating factor is the ability to form social networks. Where women live in close proximity to each other and have the social mechanism in place for quick and trustworthy communication, they have wide unofficial power to determine the direction of life in their families and communities.

Some Mediterranean societies were probably in fact more matrifocal and functionally (though not theoretically) egalitarian than we suspect. When a woman's name occurs before that of her husband, it is usually because she is of higher social status than he. ${ }^{20}$ The task here is the attempt to read between the lines of public theory, whether that be Roman law or the New Testament household codes, to ascertain how life was really lived.

The idea can be found among male writers all over the Mediterranean world that the public forum and the world of politics is male, whereas the house and the indoor life belong to women. Select passages from authors like Philo are often quoted to suggest that the women of these cultures were kept as secluded as possible. This was manifestly not the case in much of the

\footnotetext{
${ }^{19}$ See, for example, Richard A Bauman (1992), Women in politics in ancient Rome; Suzanne Dixon (1988), The Roman mother; (2001), Reading Roman women.

${ }^{20}$ Flory, Maureen Boudreau (1983/84), "Where women precede men: Factors influencing the order of names in Roman epitaphs".
} 
Mediterranean world. First of all, where such a (male) ideal existed, it was an elite picture of the family for those who had the luxury to keep (freeborn, elite) women indoors. Lower-class families could not do it. We can be sure that in spite of public ideology of the all-male forum, slave and lower-class women were there in abundance, conducting business and shopping in the market. Even classical Athens, where the ideology of seclusion appears most clearly, was not so decidedly segregated by gender in public. By the first century CE Roman women were running businesses, exercising patronage, attending public dinners, and administering their own property, in spite of formal ideology that continued to deny to them what they were actually doing. Some nonelite examples are: Julia Felix, who operated a large rental entertainment complex at Pompeii; Naevoleia Tyche, wealthy patron at Pompeii; among believers in Jesus, Lydia at Philippi (Ac 16) and Phoebe at Cenchrae (Rm 16:1-2).

\subsection{Children}

Children of a Roman citizen father and a free mother normally became citizens. In the case of noncitizen parents, the child usually took the status of the mother. Differences of legal status had severe effects on inheritance laws. A slave freed by a citizen in the correct way before a magistrate or by will normally received citizenship. From the Lex Aelia Sentia in 4 CE to Justinian in 531, informal manumission of slaves inter amicos or "among friends," or of a slave under thirty except of a female slave for marriage, inserted the newly freed slave into the category of Junian Latin, with freedom but not citizenship and no right to make a will. Their marriage was legal, iustum conubium, their children free, but unable to inherit. These restrictions often led persons to pretend to higher status than they actually possessed. There are, for instance, legal discussions about women marrying men they thought were free but turned out to be slaves. Apparently the law did not intervene unless someone who stood to suffer from the situation pressed charges. Given the widespread custom of manumitting slaves in midlife, this must have meant great numbers of children who suffered, being freeborn but with no right of inheritance from their parents. ${ }^{21}$ This would have affected Christians as well who had been slaves of Roman citizens, and their children.

Childhood was short. Children of slaves and poorer free families joined in the labor force as soon as they were able. Wealthier and upper-class children were sent to school or privately tutored on a rigorous schedule. The prevailing attitude toward children was that they were inherently resistant to civilizing, so harsh discipline was imposed to make them conform to societal expectations. The available evidence indicates that lower-class children

\footnotetext{
${ }^{21}$ Jane Gardner (1999), "Legal stumbling-blocks for lower-class families in Rome"; Paul Weaver (1999), "Children of Junian Latins".
} 
married later than upper-class children, probably because the labor of the former was needed as long as possible, while in the case of the latter, the sooner an advantageous marriage match could be made, the better.

Generally first marriages were arranged by families with the best interests of both children and their families in view. Girls were as much as ten years younger than their future husbands, sometimes more in elite situations where politics were involved. But the age disparity created many widows - one reason for the frequent mention of widows in the social-care literature of early Christianity. In second and further marriages, women seem to have exercised more choice, with husbands closer to their own age.

The Roman ideal of the once-married woman, the univira, did not hinder the practice of multiple marriages. Beginning already with 1 Cor 7 and $1 \mathrm{Tm} 3: 2,12$, we see Christian sources disparaging second marriages, which then placed on the community the burden of support of poorer widows who followed church leaders' advice.

The meeting of the Christian house church consisted of people like those described above. In some cases, a household was large enough and there were sufficient church members to constitute an ekklesia composed entirely of household members. This seems to be what is envisioned in the household of Cornelius at Caesarea (Ac 10) or that of the jailer in Philippi (Ac 16). But these are idealized narratives. The more complicated reality is reflected in the letters of Paul, where there are marriages between believers and others, and there are believing slaves in non-believing households and vice versa. In spite of the patriarchal ideology of the dominance of a male head of household, as given in Hellenistic and Roman treatises on marriage and in the household codes of the Pauline letters derived from them, the realtime discussions of family life tell a different story.

\section{AN ACTUAL EARLY CHRISTIAN FAMILY}

Into this complex and difficult world the challenge of the Jesus movement came. How it was received and how believers adapted what they already knew and were living to what they were now learning is revealed in glimpses of their writings. We have some information about the family life of one particular Christian social unit in early second-century Rome: that of Hermas as revealed in the biographical details of his narrative of the Shepherd. ${ }^{22}$ Hermas was raised as a threptos, an abandoned baby picked up and raised by someone else, probably as in most cases in slavery. At some point he was manumitted, after having been sold at least once. How and when he came

\footnotetext{
${ }^{22}$ Carolyn Osiek (1999), The Shepherd of Hermas. Some have doubted the historicity of these family details, which is irrelevant for these purposes. Whether historical or not, the story of the family is typical of its family's social location.
} 
into the Christian community is not known. At the time of writing, he is a freedman householder with an oikos, that is, a familial establishment, probably a modest domus of the kind to be seen at Pompeii or Herculaneum. Nothing is said of slave ownership, but probably slaves are present in the household. He has a wife and children, and they do appear briefly in the narrative.

Hermas is engaged in various financial ventures, and his household seems to be a rather typical Roman family of humble status but comfortable means. His wife, never named, is criticized for having too loose a tongue, a typical misogynist complaint. His children may in fact be adult children, still under his potestas, who have been behaving irresponsibly, disrespectful of his parental authority. Details are not given, except to say that they have acted lawlessly, and that Hermas, because of his affection for them, has not exercised appropriate discipline. A Roman citizen householder of any rank had legal power over all in his familia, even adult sons and daughters. He was expected to act with authority to control them. If his children were indeed adults, it would determine Hermas's age to be rather advanced as the survival norms went. Hermas is the one upon whom the blame falls for the misbehavior of both wife and children; as paternal authority, he is legally and socially responsible for the conduct of everyone under his power. Hermas is not a leader but a member of a Christian community (Vision 1.2-3). When, however, he receives his special revelation, he is instructed to read it "with the presbyters (or elders) who preside over the church" (Vision 2.4.3).

These details about the family life of Hermas are woven into the revelatory narrative of the text in such a way that it is difficult to extract them.

All is not well in either household or church of Hermas. This is perhaps a mirror of what family life in the early church was like, caught, as it always is, between ideal and reality.

\section{PRO-FAMILY PROPAGANDA}

Followers of the Jesus movement reading their own literature in the last decades of the first century CE must have thought they were receiving a confusing message. On the one hand, the household codes of Colossians and Ephesians and the domestic policies of the Pastoral Epistles and 1 Peter reinforced the family values of domestic order in a hierarchical universe (Col 3:18-4:1; Eph 5:21-6:8; 1 Tm 2:8-15; 5:11-16; 6:1-2; Tt 2:2-10; 1 Pt 2:18-3:7). As reflected in treatises on household management that had been in vogue since Aristotle, the authority of husband, father, and male slave owner is confirmed, though not without differences. However little emphasized, there is 
an articulated ideal of mutual submission (Eph 5:21). ${ }^{23}$ The role description for the dominant male is one of benevolence, not merely out of enlightened selfinterest but because of his identity in Christ along with that of all involved. He is to love his wife, not provoke his children, and treat his slaves fairly, remembering that he too has a master in heaven. ${ }^{24}$

There are other differences as well. The subordinate members of the household - wives, children, and slaves - also have a significant role to play. They are addressed and addressed first, as persons in their own right endowed with dignity. Wives become the image of the church (Eph 5:2-24), slaves of the suffering Christ (1 Pt 2:21-24). Through these passages, believers in Jesus must have gotten the same message as was communicated in civic politics and official religion: the well-run household is the foundation of society, and well-run means maintaining the hierarchical structure that had always been the philosophical and political ideal. ${ }^{25}$

Throughout all this domestic propaganda, the idealization of the structures does not change, whatever the reality. Marriage remains ideally the hierarchical relationship of benevolent monarch to his loving and submissive wife. The obedience of adult children owed by law to their paternal head is not

\section{${ }^{23}$ Ephesians 5:21-33}

Be subject to one another out of reverence for Christ.

Wives, be subject to your husbands as you are to the Lord. For the husband is the head of the wife just as Christs the head of the church, the body of which he is the Savior. Just as the church is subject to Christ, so also wives ought to be, in everything, to their husbands.

Husbands, love your wives, just as Christ loved the church and gave himself up for her, in order to make her holy by cleansing her with the washing of water by the word, so as to present the church to himself in splendor, without a spot or wrinkle or anything of the kind yes, so hat she may be holy and without blemish. In the same way, husbands should love their wives as they do their own bodies. He who loves his wife loves himself. For no one ever hates his own body, but he nourishes and tenderly cares for it, just as Christ does for the church, because we are members of his body. For this reason a man will leave his father and mother and be joined to his wife, and the two will become one flesh. This is a great mystery, and I am applying it to Christ and the church. Each of you, however, should love his wife as himself, and a wife should respect her husband.

\footnotetext{
${ }^{24}$ For discussion of the literary genre and social function of the household codes, see David $\mathrm{L}$ Balch (1988), "Household codes".

\section{${ }^{25}$ Ephesians 6}

Children, obey your parents in the Lord, for this is right. Honor your father and mother - this is the first commandment with a promise: so that it may be well with you and you may live long on the earth.

And farthers, do not provoke your children to anger, but bring them up in the discipline and instruction of the Lord.

Slaves, obey your earthly masters with great fear and trembling, in singleness of heart, as you obey Christ; not only while being watched, and in order t please them, but as slaves of Christ, doing the will of God from the heart. Render service with enthusiasm, as to the Lord and not to men and women, knowing whatever good we do, we will receive the same again from the Lord, whether we are slaves. 
compromised. Most important, the structures of slavery remain in place. In spite of Paul's Letter to Philemon, the practice of slavery continues, even if there is strong teaching that slaves are not to be mistreated. Certainly followers of Jesus were not in a political or social position to abrogate slavery, but they could have freed their own slaves. There is ample evidence that they did not. Slaves and freedmen/women continue to be incorporated into the family structure as always. They are to continue to serve wholeheartedly, not taking it upon themselves to think more of themselves or less of their masters since both are members of the assembly, but to treat their masters as they would the Lord (Eph 6:5-8; Tt 6:1-2). They are to continue to be answerable with their bodies (1 Pt 2:24). Being slave or free is proclaimed as a matter of indifference, though the opportunity for freedom is to be taken if available ( $\mathrm{Gl}$ 3:27-28; 1 Cor 7: 21-24). Slaves should not expect that funds from the assembly will be appropriated to purchase their freedom - although that must have been done in some cases, or there would have been no such expectation (Ignatius, To Polycarp 4.3). On the other hand, some take the heroic measure of selling themselves into slavery to ransom others or to secure food for the hungry (1 Clement 55.2).

\section{THE FAMILIAL COST OF DISCIPLESHIP}

While from some of their own writings the first generations of believers in Jesus were receiving a message of domestic harmony as fulfillment of the will of God, a different message, standing in some tension with the former, was coming through from another part of their tradition. The Synoptic Gospels and some of their sources conveyed the hard message of the cost of discipleship. Part of that message was the preferment of discipleship over family ties, of community cohesion over family integrity. In case of conflict, the newly constituted community was to take precedence. The tone is struck early in Mark (not the most popular early Gospel, but one surely circulating by the 80s of the first century) when Jesus' family come to take him home from his more and more popular ministry in Capernaum because they thought he was out of his mind (Mk 3:21) ${ }^{26}$ Jesus retaliates at 3:31-35 by rejecting their visit and declaring that the disciples around him are family to him. No one from Jesus' family appears again in Mark's Gospel. Matthew and Luke pick up the same story, which Luke softens considerably (Mt 12:46-50; Lk 8:19-21).

The $\mathrm{Q}$ tradition heightens the tension by having Jesus declare that one inevitable result of his preaching, in the words of Micah 7:6, is that family members will be set against each other, son against father, daughter against

\footnotetext{
${ }^{26}$ Some translations here say that it is other people, not the family, who think Jesus is out of his mind. But the Greek has an indefinite "they" and the nearest previous antecedent is oi

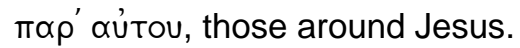


mother, daughter-in-law against mother-in-law, making one's enemies those of one's own household (Mt 10:34-35; Lk 12:51-53). Matthew goes on to say (and Luke echoes in a less determined way) that anyone who loves a family member, father, mother, son, or daughter more than Jesus is not worthy of him (Mt 10:37; Lk 14:26). Discipleship takes precedence over all family ties, even the solemn obligation of a son to bury his father (Mt 8:22; Lk 9:60). Luke softens the impact of the story of Jesus' preference for disciples over family (Lk 8:19-21), rehabilitates the mother of Jesus as prophet in the infancy narrative (Lk 1:46-55), makes John the Baptist into a relative, and suggests continuity with the family by the presence of the mother of Jesus at Pentecost and James, the brother of the Lord, as ongoing leader in the Jerusalem community. Matthew and Mark do not engage in such reconciliation. Even the Gospel of John, which does not reflect this tension about family, remarks that "even his brothers [that is, family] did not believe in him" (Jn 7:5), although he was moving about with them in Galilee.

These and sayings like them must have created confusion among families in the late first century that included a large number of followers of Jesus. It is interesting that no positive sayings about the goodness of family life were preserved and attributed to Jesus. In one sense, we could say that the strong position attributed to him with regard to prohibition of divorce (especially the extended discussion in Mk 10:2-12; Mt 19:1-9) was in fact a counterpoint affirmation of the marriage bond as core of the family and household. But these passages hardly offset the impact of others that foretell disruption, and it is noticeable that none of those passages (discussed above) speak of separation of husband and wife. Given what we know about kinship structures in antiquity and in traditional societies, especially the leading role played by parents in the arrangement of marriages and the close ties among siblings, it is unlikely that they would have said that the core of family life resided in the nuclear family (for which, by the way, they had no name). Rather, it is disruption of parent-child and sibling relationships that would have seemed more severe.

The point here is not to assess whatever historicity there may be in this Gospel tradition that relativizes family ties, though such a difficult thematic undoubtedly originated with Jesus. The point is that when the "memoirs of the apostles," as Justin calls them, were read at worship, these sayings must have been part of the readings, counteracting to some extent the domestic agenda of the Epistles cited above.

It is not a case of elite versus nonelite ideals: both visions, in fact, could be understood as elite ideals that influenced other social levels. The long tradition of structured household management based on hierarchy and submission certainly came from elite circles. At the same time, the radical philosophical teachings of some schools advocated a rupture with family ties 
similar to that attributed to Jesus, to enable the philosopher to transcend the pulls of family loyalty and transfer that loyalty to a new circle of like-minded people. The ideal of the hierarchical family certainly was reinforced by elites and was perhaps more difficult to maintain in other situations with more poverty and less education. But there is no reason to assume that lower-class families were any less devoted to each other and to preserving family unity. The lack of leisure and need for everyone to be involved in family business and labor among the lower classes may well have contributed, however, to less patriarchal and more egalitarian structures, not so much so that everyone had the same rights, as that everyone had the same obligation to join in the common labor.

The power of the family over its members could not have remained absolute through this process of competing tensions. It was relativized in favor of discipleship, the new absolute loyalty to the death. Thus, while family ties were to be respected and even strengthened when possible, they were always to be seen as secondary to the formation of a new family of believers, where old men were to be revered as one's new fathers, old women as mothers, younger men as brothers, younger women as sisters (1 Tm 5:1-2). The family ideal was not abandoned, but it was significantly altered by creating a new substitute family to whom the same loyalty was owed.

Nor did the tension with the natal family end with the New Testament. As different understandings proliferated in early Christianity, readers began to encounter slightly later and considerably more romanticized versions of apostolic adventures in what we now know as the Apocryphal Acts. Here great apostolic figures like Peter, Paul, John, and Thomas set out on their own adventurous journeys, confronting evil and conquering it. Despite some differences of theology, all of these early Christian romances have one thing in common: they all advocate celibacy as the only way of Christian existence, even if it means the breakup of marriages and espousals to accomplish it. A major difference from the Synoptic Gospels is that these stories focus on women, notably women of the upper classes. The stories in these works are full of women of leading families in their city who abandon husbands and fiancés in favor of an ascetic lifestyle in imitation and companionship with the apostle. By doing this, these tales continued the deep suspicion of the claims of the natal family and contributed to its relativization in Christian circles. The upper-class values of domestic harmony under firm male control were now under direct attack in these depictions. ${ }^{27}$

\footnotetext{
${ }^{27}$ Andrew S Jacobs (1999), "A family affair: Marriage, class, and ethics in the apocryphal Acts of the Apostles".
} 


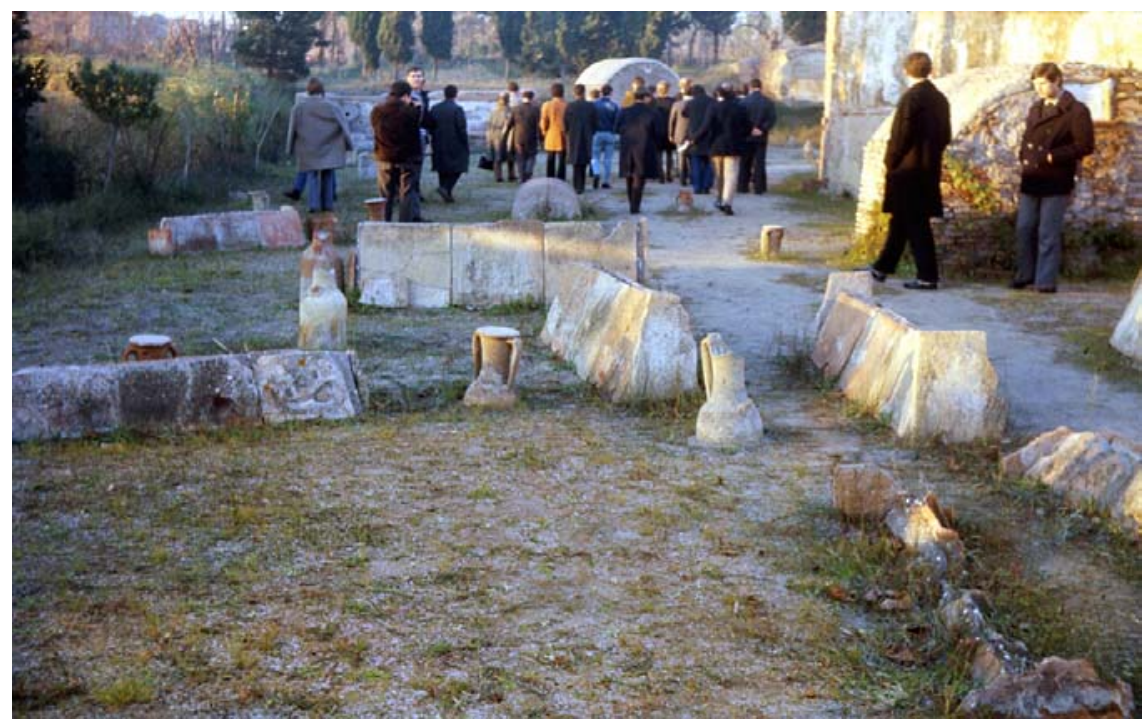

Fig 6 Inhumation and incineration burials of the poor, first - third centuries CE at Isola Sacra, the cemetery of Portus, port of Rome. While wealthier people chose family mausolea (visible in background), these represent those of more modest means, who could yet afford a decent burial rather than deposition in the common pits with the poorest people. Photo taken in 1973: these burial are no longer in place.

Photo: Carolyn Osiek

This tension between the traditional patriarchal family and the radical denial of family claims on the believer was to continue throughout early Christianity not only through official teachings but also in the cult of martyrdom and the ascetic life. In both cases, the person who resisted the claims of family with its earthly obligations in favor of renunciation of a normal family life and the embrace of death or a prolonged life of asceticism conformed to the type of heroic sanctity approved of by the same church that continued to preach the hierarchical authority of the family. The vast majority of early Christians were neither martyrs nor ascetics. They lived lives of quiet virtue and vice. As always with the silent majority, their stories go mostly untold.

\section{Works consulted}

Balch, D L 1988, Household codes, in Aune, D E (ed) Greco-Roman literature and the New Testament": Selected forms and genres, 25-50. Atlanta, GA: Scholars Press.

Balch, D L \& Osiek, C (eds) 2003. Early Christian families in context: An interdisciplinary dialogue. Grand Rapids, MI: Eerdmans.

Bauman, R A 1992. Women in politics in ancient Rome. London: Routledge.

Boudreau, F M 1983/84. Where women precede men: Factors influencing the order of names in Roman epitaphs. Classical Journal 79(2), 216-224.

Callahan, A D, Horsley, R A \& Smith, A (eds) 1998. Slavery in text and interpretation. Atlanta, GA: Society of Biblical Literature. (Semeia 83/84.)

Clarke, J R 2003. Art in the lives of ordinary Romans: Visual representations and the non-elite viewers in Italy, 100 BC-AD. Berkeley: University of California Press. 
Clarke, J R 1998. Looking at lovemaking: Constructions of sexuality in Roman art $100 B C-A D$ 250. Berkeley, CA: University of California Press.

Dixon, S 1988. The Roman mother. London: Routledge.

Dixon, S 2001. Reading Roman women. London: Duckworth.

Evans-Grubbs, Judith 1993. "Marriage more shameful than adultery": Slave-mistress relationships, "mixed marriages," and late Roman law. Phoenix 47, 125-154.

Gardner, J 1999. Legal stumbling-blocks for lower-class families in Rome, in Rawson, B \& Weaver, P (eds), The Roman family in Italy: Status, sentiment, space, 35-53. London: Oxford University Press.

Garnsey, P 1999. Sons, slaves - and Christians, in Rawson, B \& Weaver, P (eds), The Roman family in Italy: Status, sentiment, space, 100-121. London: Oxford University Press.

Glancy, J A 2002. Slavery in early Christianity. Oxford: Oxford University Press.

Harrill, J A 2003. The domestic enemy: A moral polarity of household slaves in Early Christian apologies and martyrdoms, in Balch, D \& Osiek, C (eds ), Early Christian families in context: An interdisciplinary dialogue, 231-254. Grand Rapids, MI: Eerdmans.

Jacobs, A S 1999. A family affair: Marriage, class, and ethics in the apocryphal acts of the apostles. Journal of Early Christian Studies 7, 105-138.

Judge, E A 1960. The social pattern of the Christian groups in the first century: Some prolegomena to the study of the New Testament ideas of social obligation. London: Tyndale.

Kyle, D G 1998. Spectacles of death in ancient Rome. London: Routledge.

Kyle, D G 1990. Fatal charades: Roman executions staged as mythological enactments. Journal of Roman Studies 80, 44-73.

Malina, B J 2000. Social ranking, morality, and daily life, in Esler, P F (ed), The early Christian world, vol 1, 369-400. London: Routledge.

Martin, D 1990. Slavery as salvation: The metaphor of salvation in Pauline Christianity. New Haven, CT: Yale University Press.

Martin, D B 2003. Slave families and slaves in families, in Balch, D \& Osiek, C (eds), Early Christian families in context: An interdisciplinary dialogue, 207-230. Grand Rapids, Ml: Eerdmans.

Oakes, P S 2001. Philippians: From people to Letter. Cambridge: Cambridge University Press.

Osiek, C \& Balch, D L 1997. Families in the New Testament world: Households and house churches. Louisville, KY: Westminster John Knox.

Osiek, C 1999. The Shepherd of Hermas (Minneapolis, MN: Augsburg Fortress. (Hermeneia.)

Osiek, C \& MacDonald, M (with Tulloch, J H) 2006. A woman's place: House churches in earliest Christianity. Minneapolis, MA: Fortress.

Patterson, O 1982. Slavery as social death: A comparative study. Cambridge, MA: Harvard University Press.

Pilch, J 1993. "Beat his ribs while he is young" (Sir 30:12): A window on the Mediterranean world. BTB 23, 101-113.

Rawson B 1974. Roman concubinage and other de facto marriages. Transactions of the American Philological Association 104, 279-305.

Rohrbaugh, R L 1983. Methodological considerations in the debate over the social class status of early Christians. JAAR 52(3), 519-546. 
Saller, R P 1994. Patriarchy, property and death in the Roman family. Cambridge: Cambridge University Press.

Scobie, A 1986. Slums, sanitation, and mortality in the Roman world. Klio 68, 39-433. Weaver, P 1999. Children of Junian Latins, in Rawson, B \& Weaver, P (eds), The Roman family in Italy: Status, sentiment, space, 355-72. London: Oxford University Press. 